\title{
Criteria for Good Qualitative Research: A Comprehensive Review
}

\author{
${\text { Drishti } \text { Yadav }^{1} \text { (D) }}$
}

Accepted: 28 August 2021/Published online: 18 September 2021

(C) The Author(s) 2021

\begin{abstract}
This review aims to synthesize a published set of evaluative criteria for good qualitative research. The aim is to shed light on existing standards for assessing the rigor of qualitative research encompassing a range of epistemological and ontological standpoints. Using a systematic search strategy, published journal articles that deliberate criteria for rigorous research were identified. Then, references of relevant articles were surveyed to find noteworthy, distinct, and well-defined pointers to good qualitative research. This review presents an investigative assessment of the pivotal features in qualitative research that can permit the readers to pass judgment on its quality and to condemn it as good research when objectively and adequately utilized. Overall, this review underlines the crux of qualitative research and accentuates the necessity to evaluate such research by the very tenets of its being. It also offers some prospects and recommendations to improve the quality of qualitative research. Based on the findings of this review, it is concluded that quality criteria are the aftereffect of socio-institutional procedures and existing paradigmatic conducts. Owing to the paradigmatic diversity of qualitative research, a single and specific set of quality criteria is neither feasible nor anticipated. Since qualitative research is not a cohesive discipline, researchers need to educate and familiarize themselves with applicable norms and decisive factors to evaluate qualitative research from within its theoretical and methodological framework of origin.
\end{abstract}

Drishti Yadav

drish131196@gmail.com

1 Faculty of Informatics, Technische Universität Wien, 1040 Vienna, Austria
Keywords Qualitative research · Evaluative criteria · Assessment · Quality

\section{Introduction}

“... It is important to regularly dialogue about what makes for good qualitative research" (Tracy, 2010, p. 837)

To decide what represents good qualitative research is highly debatable. There are numerous methods that are contained within qualitative research and that are established on diverse philosophical perspectives. Bryman et al., (2008, p. 262) suggest that "It is widely assumed that whereas quality criteria for quantitative research are wellknown and widely agreed, this is not the case for qualitative research." Hence, the question "how to evaluate the quality of qualitative research" has been continuously debated. There are many areas of science and technology wherein these debates on the assessment of qualitative research have taken place. Examples include various areas of psychology: general psychology (Madill et al., 2000); counseling psychology (Morrow, 2005); and clinical psychology (Barker \& Pistrang, 2005), and other disciplines of social sciences: social policy (Bryman et al., 2008); health research (Sparkes, 2001); business and management research (Johnson et al., 2006); information systems (Klein \& Myers, 1999); and environmental studies (Reid \& Gough, 2000). In the literature, these debates are enthused by the impression that the blanket application of criteria for good qualitative research developed around the positivist paradigm is improper. Such debates are based on the wide range of philosophical backgrounds within which qualitative research is conducted (e.g., Sandberg, 2000; 
Schwandt, 1996). The existence of methodological diversity led to the formulation of different sets of criteria applicable to qualitative research.

Among qualitative researchers, the dilemma of governing the measures to assess the quality of research is not a new phenomenon, especially when the virtuous triad of objectivity, reliability, and validity (Spencer et al., 2004) are not adequate. Occasionally, the criteria of quantitative research are used to evaluate qualitative research (Cohen \& Crabtree, 2008; Lather, 2004). Indeed, Howe (2004) claims that the prevailing paradigm in educational research is scientifically based experimental research. Hypotheses and conjectures about the preeminence of quantitative research can weaken the worth and usefulness of qualitative research by neglecting the prominence of harmonizing match for purpose on research paradigm, the epistemological stance of the researcher, and the choice of methodology. Researchers have been reprimanded concerning this in "paradigmatic controversies, contradictions, and emerging confluences" (Lincoln \& Guba, 2000).

In general, qualitative research tends to come from a very different paradigmatic stance and intrinsically demands distinctive and out-of-the-ordinary criteria for evaluating good research and varieties of research contributions that can be made. This review attempts to present a series of evaluative criteria for qualitative researchers, arguing that their choice of criteria needs to be compatible with the unique nature of the research in question (its methodology, aims, and assumptions). This review aims to assist researchers in identifying some of the indispensable features or markers of high-quality qualitative research. In a nutshell, the purpose of this systematic literature review is to analyze the existing knowledge on high-quality qualitative research and to verify the existence of research studies dealing with the critical assessment of qualitative research based on the concept of diverse paradigmatic stances. Contrary to the existing reviews, this review also suggests some critical directions to follow to improve the quality of qualitative research in different epistemological and ontological perspectives. This review is also intended to provide guidelines for the acceleration of future developments and dialogues among qualitative researchers in the context of assessing the qualitative research.

The rest of this review article is structured in the following fashion: Sect. Methods describes the method followed for performing this review. Section Criteria for Evaluating Qualitative Studies provides a comprehensive description of the criteria for evaluating qualitative studies. This section is followed by a summary of the strategies to improve the quality of qualitative research in Sect. Improving Quality: Strategies. Section How to Assess the Quality of the Research Findings? provides details on how to assess the quality of the research findings. After that, some of the quality checklists (as tools to evaluate quality) are discussed in Sect. Quality Checklists: Tools for Assessing the Quality. At last, the review ends with the concluding remarks presented in Sect. Conclusions, Future Directions and Outlook. Some prospects in qualitative research for enhancing its quality and usefulness in the social and techno-scientific research community are also presented in Sect. Conclusions, Future Directions and Outlook.

\section{Methods}

For this review, a comprehensive literature search was performed from many databases using generic search terms such as Qualitative Research, Criteria, etc. The following databases were chosen for the literature search based on the high number of results: IEEE Explore, ScienceDirect, PubMed, Google Scholar, and Web of Science. The following keywords (and their combinations using Boolean connectives OR/AND) were adopted for the literature search: qualitative research, criteria, quality, assessment, and validity. The synonyms for these keywords were collected and arranged in a logical structure (see Table 1). All publications in journals and conference proceedings later than 1950 till 2021 were considered for the search. Other articles extracted from the references of the papers identified in the electronic search were also included. A large number of publications on qualitative research were retrieved during the initial screening. Hence, to include the searches with the main focus on criteria for good qualitative research, an inclusion criterion was utilized in the search string.

From the selected databases, the search retrieved a total of 765 publications. Then, the duplicate records were removed. After that, based on the title and abstract, the remaining 426 publications were screened for their relevance by using the following inclusion and exclusion criteria (see Table 2). Publications focusing on evaluation criteria for good qualitative research were included, whereas those works which delivered theoretical concepts

Table 1 Final search term used for the literature search

(Qualitative research OR Qualitative criteria OR Qualitative studies)

AND

(Evaluation OR Assessment OR Identification OR Understanding) AND

(Quality OR Rigor OR Criteria OR Analysis)

AND NOT

(Quantitative research) 
Table 2 Inclusion and exclusion criteria for literature search

\begin{tabular}{ll}
\hline Inclusion criteria & Exclusion criteria \\
\hline $\begin{array}{l}\text { - Papers which deal with evaluation of qualitative } \\
\text { research }\end{array}$ & - Pure discussion and opinion papers \\
$\begin{array}{ll}\text { - Papers dealing with quality criteria, analysis and } \\
\text { understanding of qualitative studies }\end{array}$ & $\begin{array}{l}\text { - Studies available only in the form of abstracts } \\
\text { than one journal) }\end{array}$ \\
$\begin{array}{ll}\text { - Papers which were written in English } & \text { - Research focusing issues other than qualitative research or where qualitative research } \\
\text { - Papers published later than 1950 } & \text { is mentioned only as a general introductory term in the paper's abstract }\end{array}$ & $\begin{array}{l}\text { - Papers were also excluded if they only delivered theoretical concepts on qualitative } \\
\text { research } \\
\text { - If the paper was a summary of a workshop }\end{array}$ \\
&
\end{tabular}

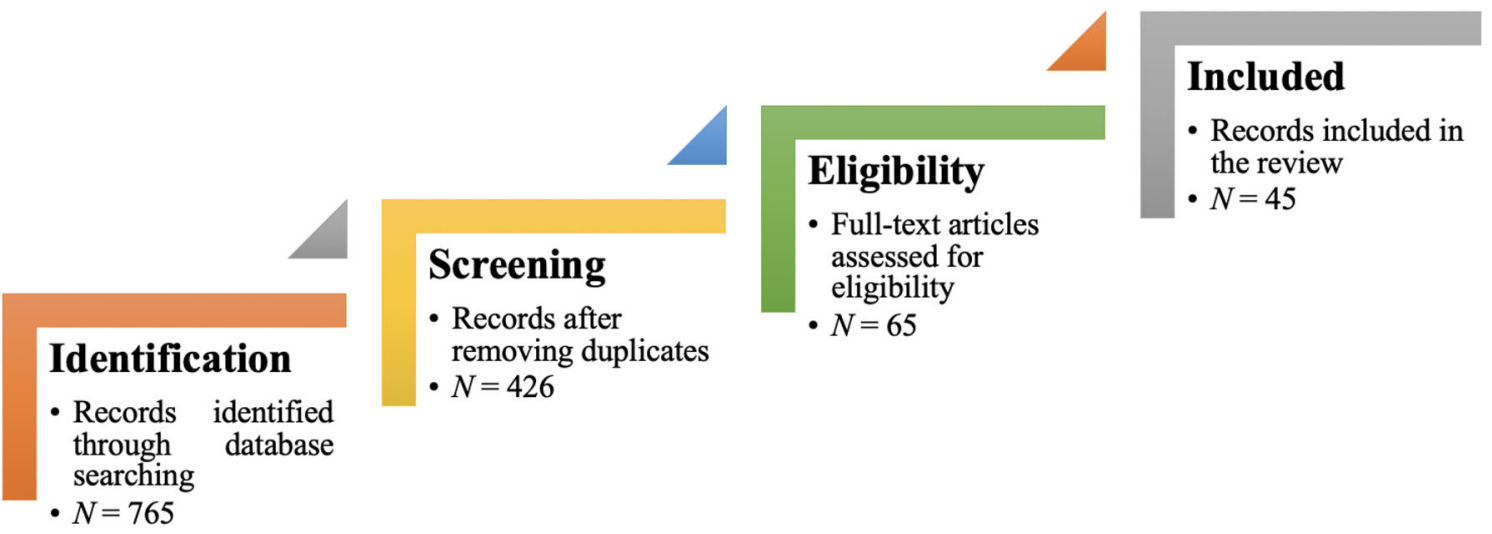

Fig. 1 PRISMA flow diagram illustrating the search and inclusion process. $N$ represents the number of records

on qualitative research were excluded. Based on the screening and eligibility, 45 research articles were identified that offered explicit criteria for evaluating the quality of qualitative research and were found to be relevant to this review.

Figure 1 illustrates the complete review process in the form of PRISMA flow diagram. PRISMA, i.e., "preferred reporting items for systematic reviews and meta-analyses" is employed in systematic reviews to refine the quality of reporting.

\section{Criteria for Evaluating Qualitative Studies}

\section{Fundamental Criteria: General Research Quality}

Various researchers have put forward criteria for evaluating qualitative research, which have been summarized in Table 3. Also, the criteria outlined in Table 4 effectively deliver the various approaches to evaluate and assess the quality of qualitative work. The entries in Table 4 are based on Tracy's "Eight big-tent criteria for excellent qualitative research" (Tracy, 2010). Tracy argues that high-quality qualitative work should formulate criteria focusing on the worthiness, relevance, timeliness, significance, morality, and practicality of the research topic, and the ethical stance of the research itself. Researchers have also suggested a series of questions as guiding principles to assess the quality of a qualitative study (Mays \& Pope, 2020). Nassaji (2020) argues that good qualitative research should be robust, well informed, and thoroughly documented.

\section{Qualitative Research: Interpretive Paradigms}

All qualitative researchers follow highly abstract principles which bring together beliefs about ontology, epistemology, and methodology. These beliefs govern how the researcher perceives and acts. The net, which encompasses the researcher's epistemological, ontological, and methodological premises, is referred to as a paradigm, or an interpretive structure, a "Basic set of beliefs that guides action" (Guba, 1990). Four major interpretive paradigms 
Table 3 Criteria for evaluating qualitative studies

\begin{tabular}{|c|c|c|}
\hline Ref & Highlights & Key questions and issues \\
\hline $\begin{array}{l}\text { Elliott et al. } \\
\text { (1999) }\end{array}$ & $\begin{array}{l}\text { A set of evolving guidelines: criteria for both } \\
\text { qualitative and quantitative empirical studies }\end{array}$ & $\begin{array}{l}\text { 1. Explicit scientific context and purpose } \\
\text { 2. Appropriate methods } \\
\text { 3. Respect for participants } \\
\text { 4. Specification of methods } \\
\text { 5. Appropriate discussion } \\
\text { 6. Contribution to knowledge } \\
\text { Specific guidelines for qualitative studies include: } \\
\text { O Owning one's perspective } \\
\text { Situating the sample } \\
\text { Grounding in examples } \\
\text { 口 Providing credibility checks } \\
\text { 口 Coherence } \\
\text { accomplishing general vs. specific research tasks } \\
\text { 口 Resonating with readers }\end{array}$ \\
\hline $\begin{array}{l}\text { Taylor et al. } \\
\text { (2001) }\end{array}$ & $\begin{array}{l}\text { A grounded theory approach for analyzing } \\
\text { manuscripts }\end{array}$ & $\begin{array}{l}\text { 1. What is the purpose of the study? } \\
\text { 2. How does the study build on previous research? } \\
\text { Informed by the literature } \\
\text { Theoretically framed } \\
\text { Defined terminology } \\
\text { 3. How thorough is the methodology? } \\
\text { Appropriate design } \\
\text { Descriptive sample } \\
\text { Detailed data collection and trustworthy data analysis } \\
\text { Recognition of limitations } \\
\text { 4. How are the findings presented? } \\
\text { Thick descriptive data } \\
\text { Discrete category development } \\
\text { Contradicting findings } \\
\text { 6. What are the implications and significance of the study? }\end{array}$ \\
\hline $\begin{array}{l}\text { Caelli et al. } \\
\text { (2003) }\end{array}$ & Contribute four key areas to be addressed & $\begin{array}{l}\text { 1. Theoretical positioning of the researcher } \\
\text { 2. Congruence between methodology and methods } \\
\text { 3. Strategies to establish rigor } \\
\text { 4. The analytic lens for data examination }\end{array}$ \\
\hline $\begin{array}{c}\text { Cohen and } \\
\text { Crabtree } \\
(2008)\end{array}$ & Evaluative criteria for good qualitative research & $\begin{array}{l}\text { 1. Carrying out ethical research } \\
\text { 2. Importance of the research } \\
\text { 3. Clarity and coherence of the research report } \\
\text { 4. Use of appropriate and rigorous methods } \\
\text { 5. Importance of reflexivity or attending to researcher bias } \\
\text { 6. Importance of establishing validity or credibility } \\
\text { 7. Importance of verification or reliability }\end{array}$ \\
\hline
\end{tabular}


Table 3

\begin{tabular}{|c|c|c|}
\hline \multirow[t]{7}{*}{$\operatorname{Rocco}(2010)$} & \multirow[t]{7}{*}{$\begin{array}{l}\text { Criteria for reviewers and editors to evaluate } \\
\text { qualitative empirical studies }\end{array}$} & $\begin{array}{l}\text { 1. Well articulated problem } \\
\text { 2. Grounded in the relevant literature }\end{array}$ \\
\hline & & $\begin{array}{l}\text { 3. Method, data collection tools, and steps to ensure rigor adequately } \\
\text { described and grounded in the relevant literature }\end{array}$ \\
\hline & & 4. Adequate explanation of sampling strategies and sample description \\
\hline & & 5. Data analysis process described in detail and limitations reported \\
\hline & & $\begin{array}{l}\text { 6. Findings include categories with definitions, sufficient data from } \\
\text { sufficient participants to support the category }\end{array}$ \\
\hline & & $\begin{array}{l}\text { 7. Meaningful discussion of the significance and implications of the } \\
\text { study }\end{array}$ \\
\hline & & $\begin{array}{l}\text { 8. Attention to the organization, use of headings, succinctness, editing, } \\
\text { and formatting }\end{array}$ \\
\hline \multirow[t]{6}{*}{$\begin{array}{l}\text { Meyer and } \\
\text { Dykes (2019) }\end{array}$} & \multirow[t]{6}{*}{$\begin{array}{l}\text { A set of complimentary criteria that help researchers } \\
\text { to rigorously conduct design study }\end{array}$} & $\begin{array}{l}\text { 1. Informed Existing knowledge informs design and facilitates new } \\
\text { interpretations }\end{array}$ \\
\hline & & 2. Reflexive We effect the research, and it effects us \\
\hline & & 3. Abundant More is better \\
\hline & & $\begin{array}{l}\text { 4. Plausible Knowledge claims are evidenced, appropriate, and } \\
\text { persuasive }\end{array}$ \\
\hline & & 5. Resonant The research inspires understanding and invites action \\
\hline & & 6. Transparent The reporting invites scrutiny \\
\hline
\end{tabular}

structure the qualitative research: positivist and postpositivist, constructivist interpretive, critical (Marxist, emancipatory), and feminist poststructural. The complexity of these four abstract paradigms increases at the level of concrete, specific interpretive communities. Table 5 presents these paradigms and their assumptions, including their criteria for evaluating research, and the typical form that an interpretive or theoretical statement assumes in each paradigm. Moreover, for evaluating qualitative research, quantitative conceptualizations of reliability and validity are proven to be incompatible (Horsburgh, 2003). In addition, a series of questions have been put forward in the literature to assist a reviewer (who is proficient in qualitative methods) for meticulous assessment and endorsement of qualitative research (Morse, 2003). Hammersley (2007) also suggests that guiding principles for qualitative research are advantageous, but methodological pluralism should not be simply acknowledged for all qualitative approaches. Seale (1999) also points out the significance of methodological cognizance in research studies.

Table 5 reflects that criteria for assessing the quality of qualitative research are the aftermath of socio-institutional practices and existing paradigmatic standpoints. Owing to the paradigmatic diversity of qualitative research, a single set of quality criteria is neither possible nor desirable. Hence, the researchers must be reflexive about the criteria they use in the various roles they play within their research community.

\section{Improving Quality: Strategies}

Another critical question is "How can the qualitative researchers ensure that the abovementioned quality criteria can be met?" Lincoln and Guba (1986) delineated several strategies to intensify each criteria of trustworthiness. Other researchers (Merriam \& Tisdell, 2016; Shenton, 2004) also presented such strategies. A brief description of these strategies is shown in Table 6.

It is worth mentioning that generalizability is also an integral part of qualitative research (Hays \& McKibben, 2021). In general, the guiding principle pertaining to generalizability speaks about inducing and comprehending knowledge to synthesize interpretive components of an underlying context. Table 7 summarizes the main metasynthesis steps required to ascertain generalizability in qualitative research.

Figure 2 reflects the crucial components of a conceptual framework and their contribution to decisions regarding research design, implementation, and applications of results to future thinking, study, and practice (Johnson et al., 2020). The synergy and interrelationship of these components signifies their role to different stances of a qualitative research study.

In a nutshell, to assess the rationale of a study, its conceptual framework and research question(s), quality criteria must take account of the following: lucid context for the problem statement in the introduction; well-articulated research problems and questions; precise conceptual framework; distinct research purpose; and clear 
Table 4 Summary of the "Eight big-Tent criteria for excellent qualitative research"

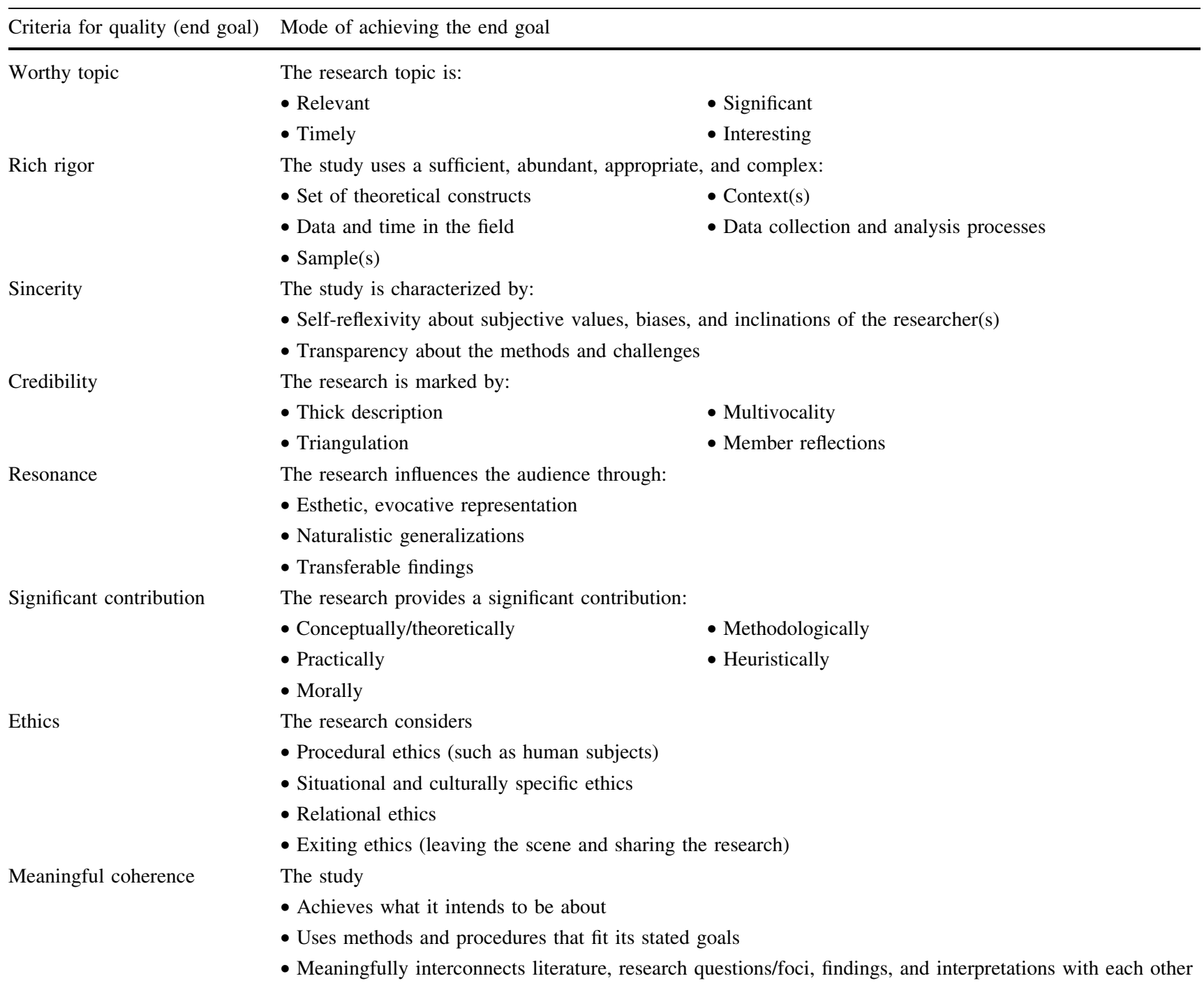

Source: Tracy (2010)

presentation and investigation of the paradigms. These criteria would expedite the quality of qualitative research.

\section{How to Assess the Quality of the Research Findings?}

The inclusion of quotes or similar research data enhances the confirmability in the write-up of the findings. The use of expressions (for instance, " $80 \%$ of all respondents agreed that" or "only one of the interviewees mentioned that") may also quantify qualitative findings (Stenfors et al., 2020). On the other hand, the persuasive reason for "why this may not help in intensifying the research" has also been provided (Monrouxe \& Rees, 2020). Further, the Discussion and Conclusion sections of an article also prove robust markers of high-quality qualitative research, as elucidated in Table 8.

\section{Quality Checklists: Tools for Assessing the Quality}

Numerous checklists are available to speed up the assessment of the quality of qualitative research. However, if used uncritically and recklessly concerning the research context, these checklists may be counterproductive. I recommend that such lists and guiding principles may assist in pinpointing the markers of high-quality qualitative research. However, considering enormous variations in the authors' theoretical and philosophical contexts, I would emphasize that high dependability on such checklists may say little about whether the findings can be applied in your 
Table 5 Interpretive paradigms and their criteria for evaluating research

\begin{tabular}{|c|c|c|c|}
\hline Paradigm/Theory & Criteria & Form of theory & Type of narration \\
\hline Positivist/postpositivist & Internal, external validity & $\begin{array}{l}\text { Logical-deductive, } \\
\text { grounded }\end{array}$ & Scientific report \\
\hline Constructivist & Trustworthiness, credibility, transferability, confirmability & Substantive-formal & $\begin{array}{l}\text { Interpretive case studies, } \\
\text { ethnographic fiction }\end{array}$ \\
\hline Feminist & $\begin{array}{l}\text { Afrocentric, lived experience, dialogue, caring, accountability, race, } \\
\text { class, gender, reflexivity, praxis, emotion, concrete grounding }\end{array}$ & Critical, standpoint & $\begin{array}{l}\text { Essays, stories, } \\
\text { experimental writing }\end{array}$ \\
\hline Ethnic & $\begin{array}{l}\text { Afrocentric, lived experience, dialogue, caring, accountability, race, } \\
\text { class, gender }\end{array}$ & $\begin{array}{l}\text { Standpoint, } \\
\text { critical, } \\
\text { historical }\end{array}$ & Essays, fables, dramas \\
\hline Marxist & Emancipatory theory, falsifiability dialogical, race, class, gender & $\begin{array}{l}\text { Critical, historical, } \\
\text { economic }\end{array}$ & $\begin{array}{l}\text { Historical, economic, } \\
\text { sociocultural analyses }\end{array}$ \\
\hline Cultural studies & Cultural practices, praxis, social texts, subjectivities & Social criticism & $\begin{array}{l}\text { Cultural theory as } \\
\text { criticism }\end{array}$ \\
\hline Queer theory & Reflexivity, deconstruction & $\begin{array}{l}\text { Social criticism, } \\
\text { historical } \\
\text { analysis }\end{array}$ & $\begin{array}{l}\text { Theory as criticism, } \\
\text { autobiography }\end{array}$ \\
\hline
\end{tabular}

Source: Denzin and Lincoln (2005)

setting. A combination of such checklists might be appropriate for novice researchers. Some of these checklists are listed below:

- The most commonly used framework is Consolidated Criteria for Reporting Qualitative Research (COREQ) (Tong et al., 2007). This framework is recommended by some journals to be followed by the authors during article submission.

- Standards for Reporting Qualitative Research (SRQR) is another checklist that has been created particularly for medical education (O'Brien et al., 2014).

- Also, Tracy (2010) and Critical Appraisal Skills Programme (CASP, 2021) offer criteria for qualitative research relevant across methods and approaches.

- Further, researchers have also outlined different criteria as hallmarks of high-quality qualitative research. For instance, the "Road Trip Checklist" (Epp \& Otnes, 2021) provides a quick reference to specific questions to address different elements of high-quality qualitative research.

\section{Conclusions, Future Directions, and Outlook}

This work presents a broad review of the criteria for good qualitative research. In addition, this article presents an exploratory analysis of the essential elements in qualitative research that can enable the readers of qualitative work to judge it as good research when objectively and adequately utilized. In this review, some of the essential markers that indicate high-quality qualitative research have been highlighted. I scope them narrowly to achieve rigor in qualitative research and note that they do not completely cover the broader considerations necessary for high-quality research. This review points out that a universal and versatile one-size-fits-all guideline for evaluating the quality of qualitative research does not exist. In other words, this review also emphasizes the non-existence of a set of common guidelines among qualitative researchers. In unison, this review reinforces that each qualitative approach should be treated uniquely on account of its own distinctive features for different epistemological and disciplinary positions. Owing to the sensitivity of the worth of qualitative research towards the specific context and the type of paradigmatic stance, researchers should themselves analyze what approaches can be and must be tailored to ensemble the distinct characteristics of the phenomenon under investigation. Although this article does not assert to put forward a magic bullet and to provide a one-stop solution for dealing with dilemmas about how, why, or whether to evaluate the "goodness" of qualitative research, it offers a platform to assist the researchers in improving their qualitative studies. This work provides an assembly of concerns to reflect on, a series of questions to ask, and multiple sets of criteria to look at, when attempting to determine the quality of qualitative research. Overall, this review underlines the crux of qualitative research and accentuates the need to evaluate such research by the very tenets of its being. Bringing together the vital arguments and delineating the requirements that good qualitative research should satisfy, this review strives to equip the researchers as well as reviewers to make well-versed judgment about the worth and significance of the 
Table 6 Strategies to enrich trustworthiness of qualitative research

\begin{tabular}{|c|c|c|}
\hline \multicolumn{2}{|l|}{ Strategy } & \multirow{2}{*}{$\begin{array}{l}\text { Key points } \\
\text { - Cross-checking: validity of data, } \\
\text { - Use of multiple sources: data collecting methods, data, investigators, or theories }\end{array}$} \\
\hline Credibility & Triangulation & \\
\hline & $\begin{array}{l}\text { Respondent } \\
\text { validation }\end{array}$ & $\begin{array}{l}\text { - Provide tentative analysis before the respondents } \\
\text { - Taking feedback: appropriate interpretation }\end{array}$ \\
\hline & $\begin{array}{l}\text { Collecting data up to } \\
\text { saturation }\end{array}$ & $\begin{array}{l}\text { - Data collection: up to the saturation point } \\
\text { - No new data can be realistically found } \\
\text { - Search both supportive and unsupportive cases }\end{array}$ \\
\hline & Reflexivity & $\begin{array}{l}\text { Researcher's critical self-assessment of } \\
\text { - Paradigm, } \\
\text { - Preconceptions, and } \\
\text { - Biases }\end{array}$ \\
\hline & Peer review & $\begin{array}{l}\text { - Discussion with peers and colleagues } \\
\text { - Taking feedback on the findings to limit the researcher's bias }\end{array}$ \\
\hline & $\begin{array}{l}\text { Prolonged } \\
\text { engagement }\end{array}$ & $\begin{array}{l}\text { - More prolonged contact to gain trust } \\
\text { - Allows to obtain more in-depth information }\end{array}$ \\
\hline & $\begin{array}{l}\text { Persistent } \\
\text { observation }\end{array}$ & $\begin{array}{l}\text { - The tireless search of identified themes } \\
\text { - Advantage of prolonged engagement }\end{array}$ \\
\hline \multirow[t]{2}{*}{ Transferability } & Maximum variation & $\begin{array}{l}\text { - Examining characteristically distinctive samples } \\
\text { - Boosts the possibility of generalization }\end{array}$ \\
\hline & $\begin{array}{l}\text { Typical sampling } \\
\text { Thick description }\end{array}$ & $\begin{array}{l}\text { The sample that typifies the entire population } \\
\text { - Use of plentiful description and narratives - to highlight the context of the study } \\
\text { - Allow readers to capture the context and apply the findings to their surroundings }\end{array}$ \\
\hline \multirow{4}{*}{$\begin{array}{l}\text { Dependability and } \\
\text { comfortability }\end{array}$} & Audit trail & Detailing: procedures, decisions, reflections, etc. \\
\hline & Peer debriefing & $\begin{array}{l}\text { Similar to peer review, except that the external auditor is a disinterested party who has no stake in } \\
\text { the research }\end{array}$ \\
\hline & Triangulation & $\begin{array}{l}\text { To inspect and establish the credibility of qualitative findings by analyzing a research question } \\
\text { from more than one perspective* } \\
\text { - Methodological triangulation } \\
\text { - Data triangulation } \\
\text { - Investigator triangulation } \\
\text { - Theoretical triangulation } \\
\text { - Environmental triangulation }\end{array}$ \\
\hline & Reflexivity & $\begin{array}{l}\text { Researcher preconceptions about the choice of research domain, question, methodology, data } \\
\text { collection, data analysis, and in the writing and presentation of findings }\end{array}$ \\
\hline
\end{tabular}

Source: Lincoln and Guba (1986); Merriam and Tisdell (2016)

*Amin et al. (2020)

qualitative research under scrutiny. In a nutshell, a comprehensive portrayal of the research process (from the context of research to the research objectives, research questions and design, speculative foundations, and from approaches of collecting data to analyzing the results, to deriving inferences) frequently proliferates the quality of a qualitative research.

\section{Prospects: A Road Ahead for Qualitative Research}

Irrefutably, qualitative research is a vivacious and evolving discipline wherein different epistemological and disciplinary positions have their own characteristics and importance. In addition, not surprisingly, owing to the sprouting and varied features of qualitative research, no consensus has been pulled off till date. Researchers have reflected various concerns and proposed several recommendations for editors and reviewers on conducting reviews of critical qualitative research (Levitt et al., 2021; McGinley et al., 2021). Following are some prospects and a few recommendations put forward towards the maturation of qualitative research and its quality evaluation: 
Table 7 Metasynthesis steps to ascertain generalizability in qualitative research

\begin{tabular}{|c|c|}
\hline Guiding rule & Steps \\
\hline Planning & $\begin{array}{l}\text { - Identification of the research problem and the need of metasynthesis } \\
\text { - Identification of the knowledge and research gaps } \\
\text { - Creation of a research team with different personal and professional backgrounds } \\
\text { - Triangulation of theoretical perspectives to structure the rationale of the study } \\
\text { - Formulation of a central research question to ensure clarity and interpretability. (The researchers should be aware } \\
\text { that a research question may change during the qualitative inquiry) }\end{array}$ \\
\hline Search & $\begin{array}{l}\text { - Identification of the preliminary inclusion criteria based on the research question(s) } \\
\text { - Identification of fundamental studies to address the central research question } \\
\text { - Identification of inclusion and exclusion criteria } \\
\text { - Creating preregistrations-records made a priori about study designs and analysis plans and placed in open } \\
\text { repositories - to fortify the credibility and transparency of research* }\end{array}$ \\
\hline Mapping & $\begin{array}{l}\text { - Based on the systematic literature review, create a coding frame (general article descriptors, study goals and research } \\
\text { questions, theoretical framework, the context, researcher reflexivity or orientation, methodology, data collection } \\
\text { techniques and sources, data analysis approach, participant demographics and characteristics, key findings, } \\
\text { discussion, and an overall assessment of study quality) } \\
\text { - Describe the coding frame development and refinement process } \\
\text { - Evaluate the intercoder reliability of the coding frame }{ }^{\#}\end{array}$ \\
\hline Appraisal & $\begin{array}{l}\text { - Organize the key results } \\
\text { - Remain consistent with the terminology } \\
\text { - Create a table of key concepts across studies, identifying similarities and differences } \\
\text { - Analyze the results }\end{array}$ \\
\hline Synthesis & $\begin{array}{l}\text { - Build a theory from the findings } \\
\text { - Provide insights and a narrative account of the findings } \\
\text { - Provide comparative results wherever applicable }\end{array}$ \\
\hline $\begin{array}{l}\text { Report and } \\
\text { recommendations }\end{array}$ & $\begin{array}{l}\text { - Start the report by delineating the justification for the metasynthesis and theoretical background } \\
\text { - Summarize the guiding rules and the findings } \\
\text { - Provide some recommendations for practice, policy, and future research } \\
\text { - Mention the limitations (if any) }\end{array}$ \\
\hline
\end{tabular}

Source: Hays and McKibben (2021)

*Haven et al. (2020)

\#'O'Connor and Joffe (2020)

- In general, most of the manuscript and grant reviewers are not qualitative experts. Hence, it is more likely that they would prefer to adopt a broad set of criteria. However, researchers and reviewers need to keep in mind that it is inappropriate to utilize the same approaches and conducts among all qualitative research. Therefore, future work needs to focus on educating researchers and reviewers about the criteria to evaluate qualitative research from within the suitable theoretical and methodological context.

- There is an urgent need to refurbish and augment critical assessment of some well-known and widely accepted tools (including checklists such as COREQ, SRQR) to interrogate their applicability on different aspects (along with their epistemological ramifications).
- Efforts should be made towards creating more space for creativity, experimentation, and a dialogue between the diverse traditions of qualitative research. This would potentially help to avoid the enforcement of one's own set of quality criteria on the work carried out by others.

- Moreover, journal reviewers need to be aware of various methodological practices and philosophical debates.

- It is pivotal to highlight the expressions and considerations of qualitative researchers and bring them into a more open and transparent dialogue about assessing qualitative research in techno-scientific, academic, sociocultural, and political rooms.

- Frequent debates on the use of evaluative criteria are required to solve some potentially resolved issues (including the applicability of a single set of criteria in multi-disciplinary aspects). Such debates would not 


\begin{tabular}{|c|c|}
\hline \multirow{8}{*}{$\begin{array}{l}\text { Different } \\
\text { components } \\
\text { of a } \\
\text { conceptual } \\
\text { framework }\end{array}$} & Purpose: Problem formulation and objectives \\
\hline & Research questions \\
\hline & Context \\
\hline & Researcher(s): Perspective, background \\
\hline & Experiences, Theories \\
\hline & Literature review \\
\hline & Situatedness: Structure/Engagement \\
\hline & Methodology: Approaches/Methods \\
\hline
\end{tabular}

Fig. 2 Essential elements of a conceptual framework

Table 8 Strong markers of high-quality qualitative research

\begin{tabular}{lll}
\hline $\begin{array}{l}\text { Section (of } \\
\text { an article) }\end{array}$ & Importance & Key points \\
\hline Discussion & $\begin{array}{l}\text { It states how the findings } \\
\text { - Add to the existing } \\
\text { knowledge through new } \\
\text { theoretical or practical } \\
\text { interpretations }\end{array}$ & $\begin{array}{l}\text { Directly address the } \\
\text { research question and } \\
\text { place the findings in the } \\
\text { context of existing } \\
\text { literature }\end{array}$ \\
& $\begin{array}{l}\text { Link to previous relevant } \\
\text { research }\end{array}$ & $\begin{array}{l}\text { Don't go beyond the data } \\
\text { that are used to conclude } \\
\text { the findings }\end{array}$ \\
\hline
\end{tabular}

Findings may inform theory and methodology development, but they may not be directly transferrable to other social or organizational settings

only benefit the group of qualitative researchers themselves, but primarily assist in augmenting the wellbeing and vivacity of the entire discipline.

To conclude, I speculate that the criteria, and my perspective, may transfer to other methods, approaches, and contexts. I hope that they spark dialog and debate - about criteria for excellent qualitative research and the underpinnings of the discipline more broadly - and, therefore, help improve the quality of a qualitative study. Further, I anticipate that this review will assist the researchers to contemplate on the quality of their own research, to substantiate research design and help the reviewers to review qualitative research for journals. On a final note, I pinpoint the need to formulate a framework (encompassing the prerequisites of a qualitative study) by the cohesive efforts of qualitative researchers of different disciplines with different theoretic-paradigmatic origins. I believe that tailoring such a framework (of guiding principles) paves the way for qualitative researchers to consolidate the status of qualitative research in the wide-ranging open science debate. Dialogue on this issue across different approaches is crucial for the impending prospects of socio-techno-educational research.

Funding Open access funding provided by TU Wien (TUW).

\section{Declarations}

Conflict of interest The author declares no conflict of interest.

Open Access This article is licensed under a Creative Commons Attribution 4.0 International License, which permits use, sharing, adaptation, distribution and reproduction in any medium or format, as long as you give appropriate credit to the original author(s) and the source, provide a link to the Creative Commons licence, and indicate if changes were made. The images or other third party material in this article are included in the article's Creative Commons licence, unless indicated otherwise in a credit line to the material. If material is not included in the article's Creative Commons licence and your intended use is not permitted by statutory regulation or exceeds the permitted use, you will need to obtain permission directly from the copyright holder. To view a copy of this licence, visit http://creativecommons.org/licenses/by/4.0/.

\section{References}

Amin, M. E. K., Nørgaard, L. S., Cavaco, A. M., Witry, M. J., Hillman, L., Cernasev, A., \& Desselle, S. P. (2020). Establishing trustworthiness and authenticity in qualitative pharmacy research. Research in Social and Administrative Pharmacy, 16(10), 1472-1482.

Barker, C., \& Pistrang, N. (2005). Quality criteria under methodological pluralism: Implications for conducting and evaluating research. American Journal of Community Psychology, 35(3-4), 201-212.

Bryman, A., Becker, S., \& Sempik, J. (2008). Quality criteria for quantitative, qualitative and mixed methods research: A view from social policy. International Journal of Social Research Methodology, 11(4), 261-276.

Caelli, K., Ray, L., \& Mill, J. (2003). 'Clear as mud': Toward greater clarity in generic qualitative research. International Journal of Qualitative Methods, 2(2), 1-13.

CASP (2021). CASP checklists. Retrieved May 2021 from https://casp-uk.net/casp-tools-checklists/

Cohen, D. J., \& Crabtree, B. F. (2008). Evaluative criteria for qualitative research in health care: Controversies and recommendations. The Annals of Family Medicine, 6(4), 331-339.

Denzin, N. K., \& Lincoln, Y. S. (2005). Introduction: The discipline and practice of qualitative research. In N. K. Denzin \& Y. S. Lincoln (Eds.), The sage handbook of qualitative research (pp. 1-32). Sage Publications Ltd.

Elliott, R., Fischer, C. T., \& Rennie, D. L. (1999). Evolving guidelines for publication of qualitative research studies in psychology and related fields. British Journal of Clinical Psychology, 38(3), 215-229.

Epp, A. M., \& Otnes, C. C. (2021). High-quality qualitative research: Getting into gear. Journal of Service Research. https://doi.org/10.1177/1094670520961445

Guba, E. G. (1990). The paradigm dialog. In Alternative paradigms conference, mar, 1989, Indiana u, school of education, San Francisco, ca, us. Sage Publications, Inc. 
Hammersley, M. (2007). The issue of quality in qualitative research. International Journal of Research and Method in Education, 30(3), 287-305.

Haven, T. L., Errington, T. M., Gleditsch, K. S., van Grootel, L., Jacobs, A. M., Kern, F. G., \& Mokkink, L. B. (2020). Preregistering qualitative research: A Delphi study. International Journal of Qualitative Methods, 19, 1609406920976417.

Hays, D. G., \& McKibben, W. B. (2021). Promoting rigorous research: Generalizability and qualitative research. Journal of Counseling and Development, 99(2), 178-188.

Horsburgh, D. (2003). Evaluation of qualitative research. Journal of Clinical Nursing, 12(2), 307-312.

Howe, K. R. (2004). A critique of experimentalism. Qualitative Inquiry, 10(1), 42-46.

Johnson, J. L., Adkins, D., \& Chauvin, S. (2020). A review of the quality indicators of rigor in qualitative research. American Journal of Pharmaceutical Education, 84(1), 7120.

Johnson, P., Buehring, A., Cassell, C., \& Symon, G. (2006). Evaluating qualitative management research: Towards a contingent criteriology. International Journal of Management Reviews, $8(3), 131-156$.

Klein, H. K., \& Myers, M. D. (1999). A set of principles for conducting and evaluating interpretive field studies in information systems. MIS Quarterly, 23(1), 67-93.

Lather, P. (2004). This is your father's paradigm: Government intrusion and the case of qualitative research in education. Qualitative Inquiry, 10(1), 15-34.

Levitt, H. M., Morrill, Z., Collins, K. M., \& Rizo, J. L. (2021). The methodological integrity of critical qualitative research: Principles to support design and research review. Journal of Counseling Psychology, 68(3), 357.

Lincoln, Y. S., \& Guba, E. G. (1986). But is it rigorous? Trustworthiness and authenticity in naturalistic evaluation. New Directions for Program Evaluation, 1986(30), 73-84.

Lincoln, Y. S., \& Guba, E. G. (2000). Paradigmatic controversies, contradictions and emerging confluences. In N. K. Denzin \& Y. S. Lincoln (Eds.), Handbook of qualitative research (2nd ed., pp. 163-188). Sage Publications.

Madill, A., Jordan, A., \& Shirley, C. (2000). Objectivity and reliability in qualitative analysis: Realist, contextualist and radical constructionist epistemologies. British Journal of Psychology, 91(1), 1-20.

Mays, N., \& Pope, C. (2020). Quality in qualitative research. Qualitative Research in Health Care. https://doi.org/10.1002/9781119410867.ch15

McGinley, S., Wei, W., Zhang, L., \& Zheng, Y. (2021). The state of qualitative research in hospitality: A 5-year review 2014 to 2019. Cornell Hospitality Quarterly, 62(1), 8-20.

Merriam, S., \& Tisdell, E. (2016). Qualitative research: A guide to design and implementation. San Francisco, US.

Meyer, M., \& Dykes, J. (2019). Criteria for rigor in visualization design study. IEEE Transactions on Visualization and Computer Graphics, 26(1), 87-97.

Monrouxe, L. V., \& Rees, C. E. (2020). When I say... quantification in qualitative research. Medical Education, 54(3), 186-187.
Morrow, S. L. (2005). Quality and trustworthiness in qualitative research in counseling psychology. Journal of Counseling Psychology, 52(2), 250.

Morse, J. M. (2003). A review committee's guide for evaluating qualitative proposals. Qualitative Health Research, 13(6), $833-851$.

Nassaji, H. (2020). Good qualitative research. Language Teaching Research, 24(4), 427-431.

O’Brien, B. C., Harris, I. B., Beckman, T. J., Reed, D. A., \& Cook, D. A. (2014). Standards for reporting qualitative research: A synthesis of recommendations. Academic Medicine, 89(9), $1245-1251$.

O'Connor, C., \& Joffe, H. (2020). Intercoder reliability in qualitative research: Debates and practical guidelines. International Journal of Qualitative Methods, 19, 1609406919899220.

Reid, A., \& Gough, S. (2000). Guidelines for reporting and evaluating qualitative research: What are the alternatives? Environmental Education Research, 6(1), 59-91.

Rocco, T. S. (2010). Criteria for evaluating qualitative studies. Human Resource Development International. https://doi.org/10.1080/13678868.2010.501959

Sandberg, J. (2000). Understanding human competence at work: An interpretative approach. Academy of Management Journal, 43(1), 9-25.

Schwandt, T. A. (1996). Farewell to criteriology. Qualitative Inquiry, 2(1), 58-72.

Seale, C. (1999). Quality in qualitative research. Qualitative Inquiry, 5(4), 465-478.

Shenton, A. K. (2004). Strategies for ensuring trustworthiness in qualitative research projects. Education for Information, 22(2), 63-75.

Sparkes, A. C. (2001). Myth 94: Qualitative health researchers will agree about validity. Qualitative Health Research, 11(4), $538-552$.

Spencer, L., Ritchie, J., Lewis, J., \& Dillon, L. (2004). Quality in qualitative evaluation: A framework for assessing research evidence.

Stenfors, T., Kajamaa, A., \& Bennett, D. (2020). How to assess the quality of qualitative research. The Clinical Teacher, 17(6), 596-599.

Taylor, E. W., Beck, J., \& Ainsworth, E. (2001). Publishing qualitative adult education research: A peer review perspective. Studies in the Education of Adults, 33(2), 163-179.

Tong, A., Sainsbury, P., \& Craig, J. (2007). Consolidated criteria for reporting qualitative research (COREQ): A 32-item checklist for interviews and focus groups. International Journal for Quality in Health Care, 19(6), 349-357.

Tracy, S. J. (2010). Qualitative quality: Eight "big-tent" criteria for excellent qualitative research. Qualitative Inquiry, 16(10), $837-851$.

Publisher's Note Springer Nature remains neutral with regard to jurisdictional claims in published maps and institutional affiliations. 